\title{
EU Rural Development Policy in the New Member States: \\ Promoting Multifunctionality?
}

\author{
Irina Râmniceanu\# and Robert Ackrill*
}

* Corresponding Author; Nottingham Trent University; robert.ackrill@ntu.ac.uk

Department of Accounting, Finance and Economics

Nottingham Business School

Nottingham Trent University

Burton Street

Nottingham

NG1 4BU

UK

Tel: +44 115848 4234; Fax: +44 1158486512

\# European Institute of Romania and Academy of Economic Studies, Bucharest

European Institute of Romania

Bd Regina Elisabeta 7-9, Sector 3

RO-030016 Bucharest

Romania

e-mail: Irina.Ramniceanu@ier.ro

Tel: +40 213142696

Fax: +40213142666
Academy of Economic Studies

Faculty of International Business and

Economics

Str Mihai Eminescu 13-15, Sector 1

Bucharest

Romania 


\title{
EU Rural Development Policy in the New Member States: \\ Promoting Multifunctionality?
}

\begin{abstract}
European Union (EU) enlargement has seen ten new member states (NMS) adopt the full range of EU policies. Within this, the rural development arm of the Common Agricultural Policy offers particular points of interest. Member states chose from an extensive list of policy measures developed within the EU15 and intended, in particular, to operationalise the concept of rural multifunctionality within the ongoing CAP reform process. This paper identifies the rural development policy choices made by the eight central and eastern European NMS and develops a taxonomy to ascertain the extent to which the NMS are directing public funds to promote multifunctionality. A number of factors are then identified as helping to influence the policy choices made across countries.
\end{abstract}

Key Words: rural development, new member states, multifunctionality, competitiveness, policy choices 


\section{Introduction}

The Common Agricultural Policy (CAP) has, since 1992, undergone enormous change. The instruments of price support have, for most commodities, been replaced progressively with direct payments that distort prices and trade much less. Furthermore, from 1999 a new second 'Pillar' of CAP support - rural development has sought to promote a multifunctional role for agriculture, even providing support for non-agricultural activities. Thus the CAP has been re-focused, although spending has been maintained.

The 2004 EU enlargement thus saw ten new member states (NMS) implementing a CAP shaped by policy pressures in the EU15, including the promotion of multifunctionality. This paper focuses on the first step taken by the NMS in implementing EU rural development policy: the choices they made from the menu of policy measures available (we exclude Cyprus and Malta, given their different recent economic histories and non-participation in the pre-accession SAPARD programme). A simple framework is developed that identifies policy choices as principally multifunctionality-oriented or competitiveness-oriented, with these choices valued by reference to the public funding assigned to each measure. In contrast to much current work on rural development, this paper looks at both pre- and post-accession policy measures in all relevant rural development documentation, thus avoiding any artificial truncation of the analysis.

The paper proceeds as follows. Section 2 introduces the concept of multifunctionality and explores its place in recent work on the implementation of rural development policies in the EU. Section 3 draws on this concept to introduce the application of this concept in the NMS and establish the taxonomic framework and statistical tools used in the rest of the paper. Sections 4 and 5 apply the taxonomy to the pre-accession and post-accession rural development policy choices, respectively, whilst Section 6 presents and discusses a descriptive statistical analysis of the findings. It also considers some of the factors limiting the implementation of multifunctionality in the NMS and offers a brief comparison with the implementation of rural development policies in the EU15. Section 7 concludes. 


\section{CAP reform and the concept of multifunctionality}

Since 1992, the CAP has undergone enormous change, in two distinct ways. First, the instruments associated with price support, initially the dominant form of income support under the CAP, have been replaced progressively with instruments principally direct payments - that distort prices and trade much less (the process of 'de-coupling', weakening or breaking the policy link between the levels of support and production). Trade-related concerns have been highly influential in this ongoing reform process (see, inter alia, Swinbank and Daugbjerg, 2006), with other factors also helping change the CAP in a second way, with the CAP now embracing a wider range of goals and instruments.

These two strands reflect "longer-range structural tendencies" (Potter and Tilzey, 2005: 595). Through the World Trade Organisation (WTO) "neoliberal imperatives" (page 592) are driving a trade liberalising agenda whilst, alongside, there is a struggle between multifunctionalism (diversifying "the income base of family farms" - page 590) and neomercantilism (preserving production-based support). Europe's policy response has been to "find and defend spaces for postproductivism within an inherently productivist agriculture" (page 596). This is manifesting itself through "an increasingly bimodal rural policy" (ibid), whereby "postproductivist consumption spaces and policy strategies can co-exist alongside 'market' productivism" (page 584). Multifunctionalism is winning out over neomercantilism, not as an alternative to neoliberalism but as a policy developing alongside and in response to it.

The genesis of the current broadening of the CAP was the 1996 European Conference on Rural Development. The resulting Cork Declaration for A Living Countryside (see, inter alia, European Commission, 1997) stated, in the preamble, that the conference was "persuaded that the concept of public financial support for rural development...is increasingly gaining acceptance." Subsequently, Article 20 of the Final Act of the GATT Uruguay Round acknowledged that further reform and liberalisation of agricultural policies was needed, a process that should take into account, inter alia, "non-trade concerns". The preamble to the Agreement on Agriculture also argues for "the need to protect the environment". Thus both the EU and GATT members determined that agricultural policies should reflect the multiple functions that the agricultural sector can perform. 
These developments resulted in the 1999 CAP reform establishing a new support structure for agriculture. The measures, some new, others already in existence, were consolidated into a new 'rural development' arm of the CAP, also known as Pillar II, the (directly) income support measures being Pillar I. Through this reform process, the term 'multifunctionality' rose to prominence within the CAP lexicon (although the term is not European either in origin or exclusive application. Garzon, 2005: 3, identifies the 1992 Rio declaration on sustainable development as being the first time the term was recognised internationally whilst, inter alia, Boisvert and Blandford, 2005, apply the concept to an analysis of agricultural policy in Asia).

There are two related aspects of multifunctionality that need further exploration. One is definitional, the other is the implication multifunctionality might have for policymaking. Taking the word literally, agriculture's 'multiple functions' arise because of "the joint production of commodities and non-commodities by the agricultural sector." (Durand and van Huylenbroeck, 2003: 1). As a result of this jointness, the ways in which agriculture can produce commodity outputs influence, for example, soil and water quality, the diversity of flora and fauna, farm animal welfare and the quality of the countryside as a public amenity (OECD, 2001: 40 identifies many noncommodity outputs and their links with commodity outputs).

To the extent that a common definition exists for multifunctionality, it is based around this idea of the joint production of commodity and non-commodity outputs. The most extensive work undertaken to clarify these ideas has been done by the OECD (see, in particular, OECD, 2001). A distinction is drawn between 'positive' and 'normative' approaches. The positive approach, which sees multifunctionality as a characteristic of farming, is based strictly on this jointness in the production of commodity and noncommodity outputs. Moreover, a policy response arises because some of the latter outputs exhibit the characteristics of externalities and public goods and thus lack complete markets (OECD, 2001: 9).

The 'normative' approach (OECD, 2001, op cit), however, sees multifunctionality as having value in itself, discussion of which requires consideration of society's concerns with and objectives for agriculture. That said, the OECD argues that the 
positive approach does not exclude the normative, since "normative aspects of multifunctionality could thus be suitably addressed in the context of empirical work on multifunctionality and policy implications." (ibid).

The policy concerns over multifunctionality arise through the ways in which countries respond to the jointness in production of commodity and non-commodity outputs and incomplete markets for the latter, in particular "the way in which scarce resources are used in the economy to meet the demands of society" (ibid). As countries reduce trade-distorting support, they may introduce new instruments to maintain the output of welfare-increasing non-commodity outputs. Other countries, however, may fear these new instruments will distort trade. Potter and Burney (2002) consider this debate in the context of the WTO talks, for the non-commodity outputs of landscape and biodiversity. They argue the EU approach to the talks assumes trade liberalisation will have an adverse impact on these outputs unless some income-support remains in agricultural policies to keep farmers on the land. They suggest that the EU may thus pursue a negotiating strategy seeking the retention of some trade-distorting support, subject to stringent environmental tests (page 46). As seen below, however, EU policy taken in the round is consistent with the normative rather than positive approach.

The positive approach and its emphasis on jointness implies that multifunctional policy goals can be achieved through policies aligned directly with farming activities. A normative approach, however, would more readily enable support to be targeted via independent policy instruments towards the activities that achieve desired societal goals. Moreover, not all of these need be directed at farmers or farming activities. The present paper thus highlights the positive-normative debate as a key area of contention in the ongoing debate over the meaning of multifunctionality.

Moreover, it is worth reiterating that the EU approach to multifunctionality, as seen in the measures implemented under Pillar II of the CAP and discussed below, follows the normative approach. Indeed, whilst the OECD may wish to avoid considering "the functions and objectives assigned to agriculture by society...[t]his is...the core of the European debate on multifunctionality." (Garzon, 2005, page 5). Lehtonen et al (2005: 2) point out, moreover, that most studies have adopted a positive approach to multifunctionality to the exclusion of "the non-public good aspects (such as rural 
viability or food security) of multifunctional agriculture", although they note the complexity of attempting to introduce such elements into "the social welfare function of agriculture". Barthelemy and Nieddu (2004: 1), from an institutional economics perspective, add that there are "other ways that the market to handle agricultural non trade concerns."

Notwithstanding the multiple environmental cross-compliance conditions attached to (Pillar I) direct payments, therefore, Pillar II rural development measures go much further, to address directly environmental and other issues of concern to EU citizens. Implicit in this debate is the distinction between agricultural multifunctionality and rural multifunctionality. Given the breadth of measures implemented under Pillar II of the CAP (discussed later), this paper uses the term multifunctionality to refer to rural multifunctionality. This is consistent with the work of Rodríguez Rodríguez et al (2004) who argue in favour of a broader 'territorial' concept of rural multifunctionality (see also Section 3, below). Indeed the two variations, agricultural and rural multifunctionality, broadly reflect the OECDs positive-normative debate.

Given these competing views on multifunctionality, it is interesting to consider the findings of some of the early studies conducted to examine how countries have implemented rural development from the available menu of measures. Lowe et al (2002) examine the initial policy decision taken by France and the UK, the first two countries to make use of the rural development opportunities available via modulation - the recycling of a small portion of Pillar I direct payments into Pillar II measures. They conclude that each country has implemented rural development by choosing different combinations of measures that reflect different rural agendas.

France has implemented what Lowe et al (2002: 15) refer to as an "agrarian agenda", centred on agriculture and thus reflecting agricultural multifunctionality. The UK, however, has pursued a "countryside agenda", that "is not so much agricultural survival as the provision of broader environmental public goods for a society that places particular value upon them." This approach reflects a broader rural approach to multifunctionality: in contrast to the OECD view of a normative approach to multifunctionality subsisting within a positive framework, the EU approach to rural development allows countries to adopt a policy mix consistent with the positive 
approach, but from a set of measures established in a way consistent with the normative approach. Note also Ward and Lowe (2004: 136) argue that, in England, the allocation of funds between alternative measures (90\% of money in 2000 went to agri-environmental and less-favoured area schemes) has yet to benefit "a significantly wider range of potential recipients...beyond traditional recipients."

The foregoing discussion has highlighted the contested meaning of multifunctionality and has shown, by reference to initial studies conducted in and between EU15 countries, that the menu approach to rural development policy measures can result in flexible implementation across countries. Some countries are taking a broader rural/territorial approach, whilst others are taking a narrower agricultural/sectoral approach (see also Section 6). With EU enlargement, the CAP has now been extended to ten more countries. How have they approached the question of rural development and the decision to give it a narrow sectoral or broad territorial focus?

\section{Multifunctionality and the New Member States: a framework for analysis}

The new EU member states (NMS) have, since 2004, faced a rural development policy menu essentially the same as the EU15, but with some extra measures added to address specific issues in these countries (as discussed below). Moreover, these countries were able to implement a partial rural development policy prior to accession in 2004, under the Special Accession Programme for Agriculture and Rural Development (SAPARD), choosing from a sub-set of measures based on those available to full members. Cyprus and Malta are thus excluded from the analysis in this paper,given their absence from SAPARD and different recent economic histories.

To focus analysis, rural development policy measures are divided into two groups: those principally competitiveness-oriented (' $\mathrm{C}$ ' policies) and those principally multifunctionality-oriented (' $\mathrm{M}$ ' policies). In the existing literature, no formal distinction is made in identifying measures that promote (rural) multifunctionality, although European Commission, 2003, offers a three-way split between the rural development policy measures for 2000-2006: 'restructuring/competitiveness', 'environment/land management' and 'rural economy/rural communities', although this is not legislatively-based (see also Râmniceanu, 2004). 
The present paper combines the second and third of these divisions for two reasons. First, it helps simplify and clarify the conduct and interpretation of the subsequent analysis. Second, by joining these measures together the non-commodity agricultural measures and the non-agricultural measures that, together, distinguish the normative approach to multifunctionality, are unified neatly. Note, however, that the EU groups measures differently across the SAPARD, 2000-2006 and 2007-2013 programmes. The present paper has drawn upon all three sources to produce a two-category classification consistent with the EU view.

The split of policy measures under the pre-accession SAPARD policy and postaccession (2004-2006) rural development policy are discussed below and summarised in Tables 1 and 2. Broadly speaking, $\mathrm{C}$ measures are those which seek to improve efficiency in the production of commodity outputs. Measures can be targeted at any point along the food chain from production (with measures such as investment in farms and training) through intermediate stages (such as the establishment of producer groups and investment in processing facilities), to consumers (for example activities related to marketing, or promoting food quality). Such measures complement Pillar I instruments and are consistent with the joint goals of Article 39 of the Treaty of Rome, to achieve "a fair standard of living for the agricultural community" by "ensuring the rational development of agricultural production and the optimum utilization of the factors of production".

M-oriented measures can thus be defined 'negatively' as all measures other than those which seek primarily to raise the efficiency with which resources are used to produce commodity outputs. A more 'positive' expression is that M-oriented measures are those which seek either to promote environmentally-friendly methods of farming and land management, or those which seek to promote economic diversification and the economic health of the wider rural economy and community. Note, however, that $\mathrm{M}$ measures can still improve the efficiency with which factors of production are used. As an example, diversification can generate efficiency gains through economies of scope, by spreading resources across the production of commodity and noncommodity outputs. 
Whilst the positive approach to multifunctionality recognises commodity and noncommodity outputs, the normative approach allows us to divide $\mathrm{M}$ measures further, into those having implications for the efficiency of resource-use in the production of non-commodity outputs (such as diversification) and those which do not primarily target efficiency. It is important also to note that the classification adopted in this paper is consistent with that of the European Commission. Thus, for example, whilst a general discourse on diversification may include activities like developing food processing, this latter activity is, under the CAP, supported separately and identified as a $\mathrm{C}$ measure - consistent with the definition of $\mathrm{C}$ measures adopted in this paper.

To give another example, payments that support farming in Less-Favoured Areas help address low farming incomes, but they do not primarily target efficiency in the production of commodity outputs. These payments can also be seen as M-oriented as they help preserve farming activities in areas where an exodus of farmers could have a negative environmental or cultural impact. This approach is consistent with the wider literature. Rodríguez Rodríguez et al, (2004: 5), notably, identify a series of functions for rural space beyond agriculture: ecology, cohesion, recreation, residential services and culture and education consistent with the M-classification and which are, in the present paper, seen in the context of the normative approach.

A note of clarification is also needed regarding the LEADER programme. In the 2007-2013 programming period, LEADER is identified as a distinct, fourth, axis of policy $^{1}$ (in contrast to the 2000-2006 programming period, this four-axis structure has a legislative basis). It is, however, perhaps misleading to describe LEADER thus. It operates more as a 'horizontal' instrument, addressing measures similar to those covered by the other three axes, but emphasising local development managed by local partnerships. Of more direct relevance to the present paper, the focus on the previous and current programming periods requires recognition of the fact that, until 2007, LEADER is treated differently in the EU15 and NMS, as explained later. Without a detailed breakdown of the allocation of funds between different elements under the LEADER umbrella the measure, as a whole, was aligned with $\mathrm{M}$ policies, given its broad orientation and emphasis. 
Having identified the available rural development measures as C-oriented or Moriented, the present paper then utilises a comprehensive dataset of the public funds allocated to each rural development measure in each country. This has been obtained from the pre-accession SAPARD and post-accession programming documents, for each of the eight countries analysed, the Czech Republic, Estonia, Hungary, Latvia, Lithuania, Poland, Slovakia and Slovenia. Post accession, there are two types of programme and accompanying documentation. ${ }^{2}$ Rural Development Programmes (RDPs) channel European Agricultural Guidance and Guarantee Fund (EAGGF) Guarantee-section funding, whilst Operational Programmes (OPs) or Single Programming Documents (SPDs) ${ }^{3}$ channel Guidance-section funding in Objective 1 regions. SPDs apply where the value of EU support is less than $€ 1$ billion.

Across the NMS8 all regions are classified as Objective 1 except Prague in the Czech Republic and Bratislava in Slovakia, which are Objective 2. This adds complications, because some measures are handled differently depending on whether the region is Objective 1 or Objective 2. For such measures, Slovakia directed Guarantee Funding to Bratislava through the RDP, but for the rest of the country channelled Guidance funding through the OP. The Czech Republic chose not to submit Prague into any rural development programme.

The level of public funding assigned to each measure is then aggregated to give a total sum directed towards each of the $\mathrm{C}$ and $\mathrm{M}$ categories. The analysis in subsequent sections utilises these $\mathrm{C} / \mathrm{M}$ aggregates for each country separately and for the NMS8 in total, looking at both the pre- and post-accession periods. The two types of postaccession programming document are also analysed separately.

The division of public funds between $\mathrm{C}$ and $\mathrm{M}$ measures offers a simple expression of the extent to which NMS' rural development policy choices seek to promote multifunctionality. A more formal way of expressing policy preferences is identified with reference to spending quintiles. If a country allocates more than $80 \%$ of public rural development funds to $M$ measures, that country is described as exhibiting a 'Strong M-Preference'. If the M-allocation is between $60 \%$ and $80 \%$, this represents a 'Moderate M-Preference'; for an M-allocation between 40\% and 60\%, a 'Balanced 
Approach'; between 20\% and 40\%, a 'Moderate C-Preference'; and below 20\%, a 'Strong C-Preference'.

The second part of the analysis utilises statistical correlations between the eight countries' M-shares of public funds and selected economic variables, using the correlation coefficient (' $r$ '). This approach is adopted for a variety of reasons and comes with caveats attached. The data from the programming documents are very aggregated and the number of observations is limited, to the point that econometric modelling is infeasible given the lack of degrees of freedom. Correlations offer a formal approach to analysis, based in theory.

That said, given the limited data and descriptive nature of the statistics used, the results are not offered as rigorous inferential hypothesis-testing. Instead, correlation coefficients are offered as a way of revealing possible links between policy uptake and potential causal factors. They therefore provide a feel for factors influencing rural development policy choices. As a result, to help give a broad indication of the degree of co-movement in different data series and to get away from the formality of econometric testing, we quote the $10 \%$ as well as $5 \%$ and $1 \%$ levels of significance (although 'strength' of correlation is perhaps a more appropriate concept). The $10 \%$ figure is seen to correspond to a coefficient of approximately 0.67 . The limited observations will, moreover, limit the formal power of the testing procedure. As more disaggregated data become available, so more formal quantitative analyses will become feasible. For example, Bertoni et al (2005) use regression analysis to look at the implementation of agri-environmental measures across 55 regions in the EU15.

Moreover, because we are not offering correlation coefficients as a formal method of hypothesis testing, we are not dismissing other, political or policy, factors that will doubtless also influence policy take-up. Indeed, the influence of legislative factors is highlighted throughout. What is likely, however, is that where a correlation coefficient is reasonably high, there are unlikely to be other factors providing a substantial counter-force to the economic factor being considered.

Potential cross-measure influences on take-up are not considered in this paper, for example measure accessibility (determined, inter alia, by national co-financing rates) 
and, for post-accession choices, previous implementation experience. Given strict legislative limits on, for example, co-financing rates, a study of measure accessibility may be relevant to an analysis of the take-up of different measures within a country (noting that co-financing rates vary across measures), but these legislative constraints limit measure-accessibility as a factor allowing significant variation in cross-country take-up rates for a given measure. The statistical analysis is thus offered as a starting point to help guide and contextualise more detailed and disaggregated qualitative and case-study analyses of policy take up, by measure and by country.

\section{SAPARD: Policy Choices Prior to EU Accession ${ }^{4}$}

The Special Accession Programme for Agriculture and Rural Development was established in $1999^{5}$, with the express aims (Article 1(2)) of:

"(a) contributing to the implementation of the acquis communautaire concerning the common agricultural policy and related policies;

(b) solving propriety and specific problems for the sustainable adaptation of the agricultural sector and rural areas in the applicant countries."

The applicants faced a menu of fifteen measures, shown in Table 1 (along with their $\mathrm{C}$ or M designation), but Article 4(3) stated that in making their policy choices:

"applicant countries shall ensure that priority is given to measures to improve market efficiency, quality and health standards and measures to create new employment in rural areas, in compliance with the provisions on the protection of the environment."

It is thus clear from both Articles that the EU15 wished the applicant countries to emphasise $\mathrm{C}$ measures in implementing SAPARD. Figure 1 confirms the applicants respected this. Note that all the Figures include the $\mathrm{C} / \mathrm{M}$ balance for aggregate NMS8 data ('Total') as well as each country individually, with the ranking based on (descending) M-shares. Because 'Total' is, in effect, a weighted average of the individual countries' spending allocations, it is always located between the middle of the country rankings and Poland, given that country's dominance in NMS8 spending (about $50 \%$ of the total under SAPARD and post-accession policies). 


\section{Table 1: SAPARD Policy Options Available to Applicant Countries}

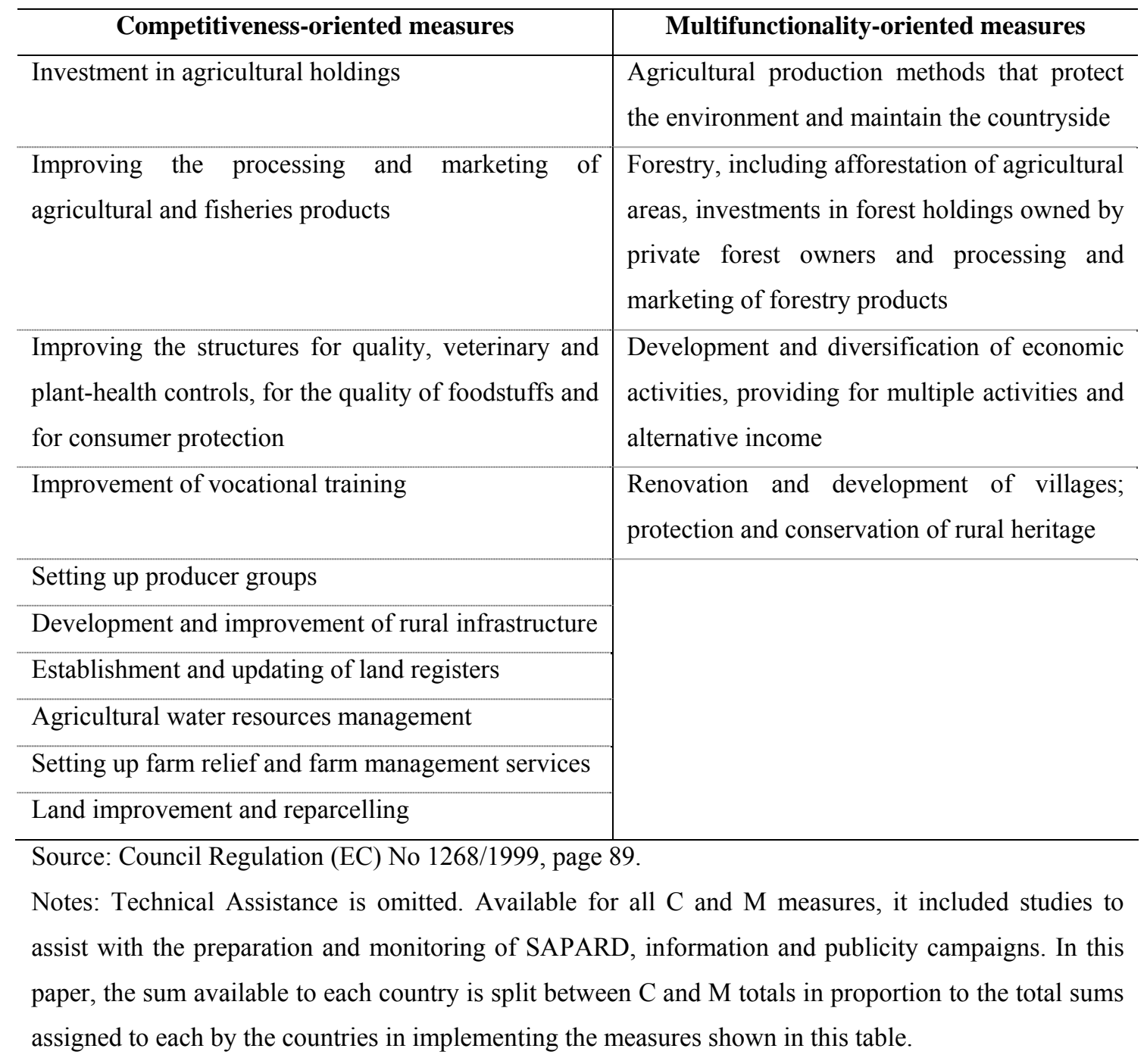

Of the fifteen available options, three were not chosen at all ${ }^{6}$. On the other hand, four measures were chosen by all eight countries ${ }^{7}$, with another three measures chosen by six or seven countries ${ }^{8}$. One stand-out feature is the different spending allocation between measures. The measures 'investment in agricultural holdings' and 'processing' took over $50 \%$ of total resources in every country except the Czech Republic. This drives the pattern seen in Figure 1, where C measures dominate.

In contrast, seven countries chose to support environmentally friendly agricultural practices, but this received only $2.1 \%$ of public funds (and just $1.2 \%$ of total funds). Slovenia chose not to utilise this policy option partly because of this limited budget (see Network of Independent Experts, 2004: 151-152; Konečný, 2004: 71). Moreover, Article 4(3) refers to environmental policy only indirectly. That said, agri- 
environmental measures under SAPARD were intended as pilot projects, with "the objective of developing practical experience of agri-environment implementation at both the administrative and farm levels" (Article 4 of Commission Regulation (EC) No 2759/1999), given concerns that inexperience could lead to implementation problems (see also Network of Independent Experts, 2004, Chapter 7).

Figure 1: Take-up of Competitiveness-Oriented and Multifunctionality-Oriented Policy Measures under SAPARD (shares of public funding)

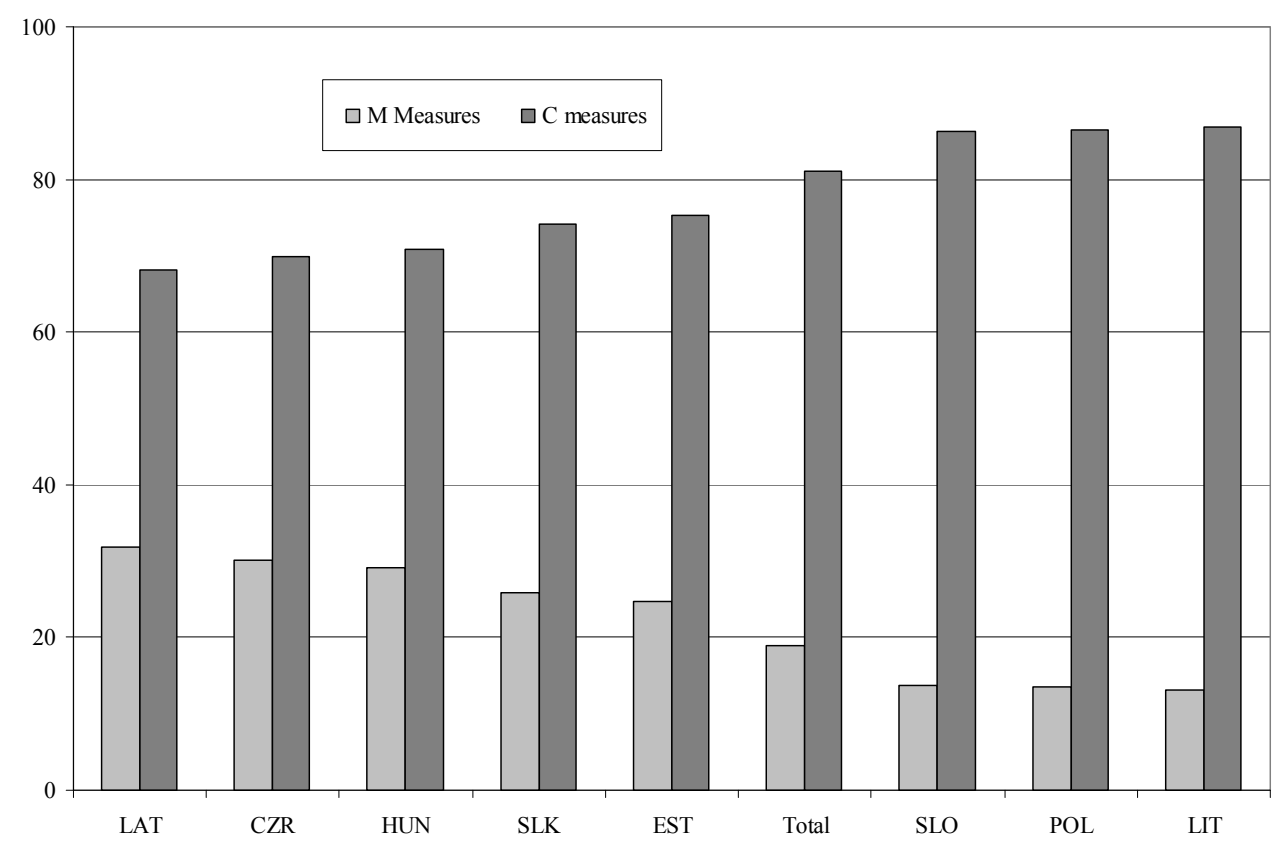

Despite the guidance on implementation provided in Article 4(3), the measures adopted were not always consistent. 'Investment in holdings', a measure that can "improve the efficiency of agriculture" was utilised in all countries, but only three countries employed 'land improvement and reparcelling' (and only the Czech Republic did so to a significant degree), whilst no country pursued the 'establishment and updating of land registers', which would have further aided restructuring. 'Quality and health standards', meanwhile, was taken up only in the Czech Republic.

The $\mathrm{M}$ measures available under SAPARD sought mainly to promote economic diversification, the one $\mathrm{M}$ measure referred to in Article 4(3) (and taken up by all eight countries). This emphasises again the importance of the 'normative' approach to understanding and analysing the multifunctional goals of EU rural development 
policy: diversification is not a joint product of farming but a measure in its own right, constituting a deliberate policy choice.

\section{Implementing rural development policy as full members, 2004-2006}

The post-accession structure of rural development policies is rather complex. As noted in Section 3, there are two sources of funding, the EAGGF guarantee and guidance sections, channelled through two different programmes. Moreover, some measures will be supported by one or other programme, depending on whether the recipient region is classified as Objective 1 or Objective 2. Further clarifying comments are also required concerning individual policy measures.

For the NMS thirty one measures (see Table 2) exist across several Regulations, twenty seven of which apply to the EU25. Measure 'w', "management of integrated rural development strategies by local partners", is not applicable in the NMS as such. It offers EU15 countries the option to implement the otherwise distinct local LEADER+ measures through "mainstream [rural development] programmes" (Preamble to Council Regulation 583/2004). For the NMS, measure ' $w$ ' is superfluous as they can implement LEADER-type measures directly through Objective 1 documentation (Articles 33f and 47a of Council Regulation 1257/1999).

Four measures were introduced specifically for the NMS via the Act of Accession (two more measures, 'complements to state aid in Malta' (af) and 'full-time farmers in Malta' (ag), are excluded from this paper). 'Semi subsistence farming' and 'setting up producer groups' are shown in Table 2. Money assigned to the third measure, 'technical assistance', is incorporated into Figure 2 by splitting the figure between $\mathrm{C}$ and $\mathrm{M}$ sub-totals in proportion to the ratio of these two sub-totals (based on measures ' $a$ '- 'ac'). The fourth measure is 'complements to direct payments'. Initially, the NMS can 'reverse-modulate' rural development money, whereby money is removed from Pillar II projects and used to top-up (Pillar I) direct payments. This is excluded from the main analysis, which focuses on actual funding for rural development measures, although a few comments on this measure are made at the end of Section 6. 
Table 2: Rural Development Policy Measures, Document Type and Policy Orientation

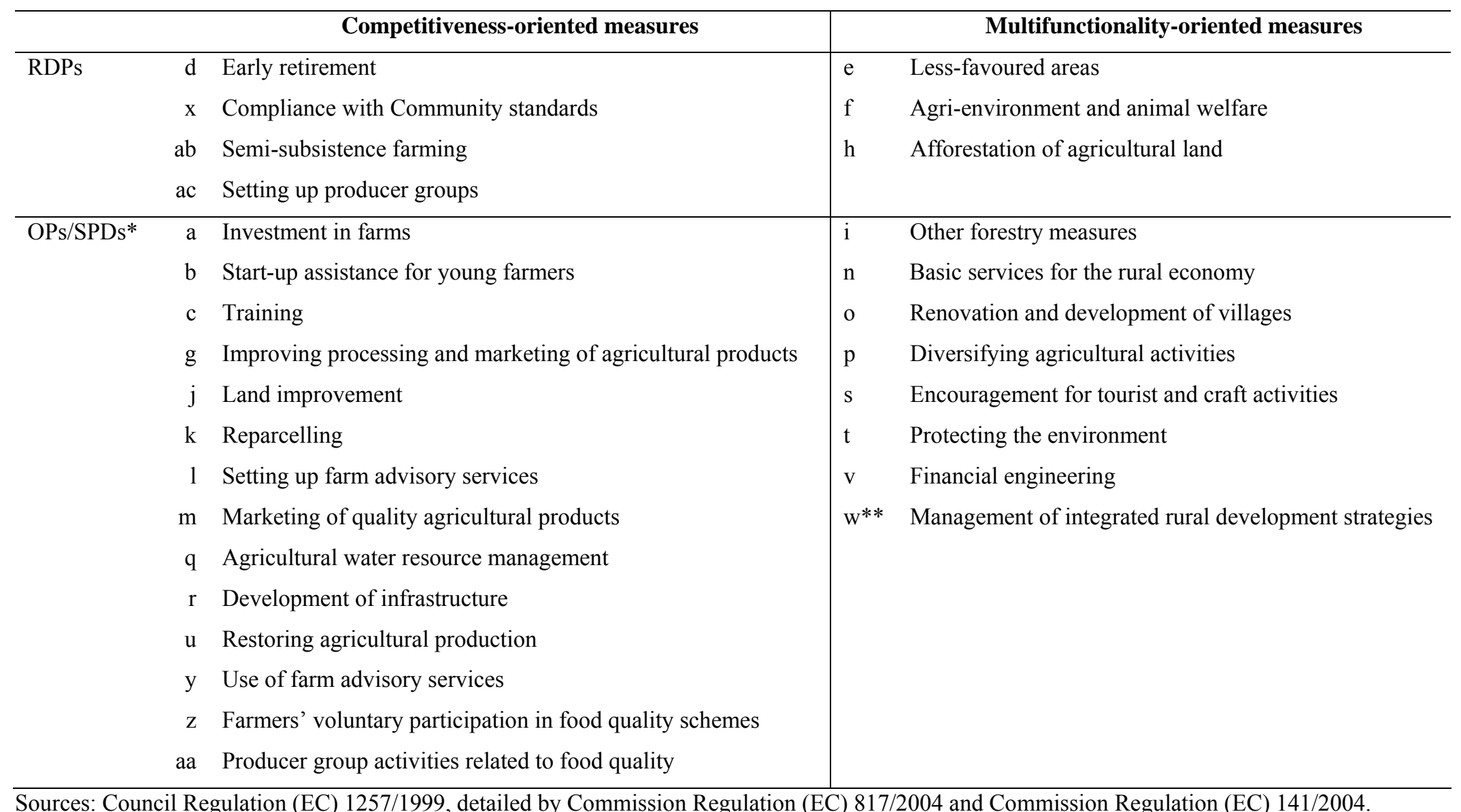

Sources: Council Regulation (EC) 1257/1999, detailed by Commission Regulation (EC) 817/2004 and Commission Regulation (EC) 141/2004.

Notes: The letters identifying each measure are taken from the relevant Regulations.

* Some of these measures may, in the case of Objective 2 regions, also be included in RDPs. ** LEADER-type measures in the NMS. 


\subsection{National Rural Development Plans: 'Guarantee’ Funding}

Table 2 shows just seven measures implemented through RDPs (plus 'technical assistance', with 'complements to direct payments' excluded), although they channel about two-thirds of public rural development funding in the NMS. Compared with SAPARD policy choices, it is clear from Figure 2 that RDPs have a much greater emphasis on $\mathrm{M}$ measures. Of the seven Objective 1 measures taken up, over one-third of available funding is devoted to less favoured areas (a measure excluded from SAPARD), with another quarter supporting agri-environmental and animal welfare measures. Even so, although the NMS are obliged to implement agri-environmental policies, the extent of uptake ranges from $66 \%$ of public funding on $\mathrm{M}$ measures in Hungary, to $12 \%$ in Latvia.

Figure 2: Take-up of Competitiveness-Oriented and Multifunctionality-Oriented Policy Measures under RDPs (shares of public funding)

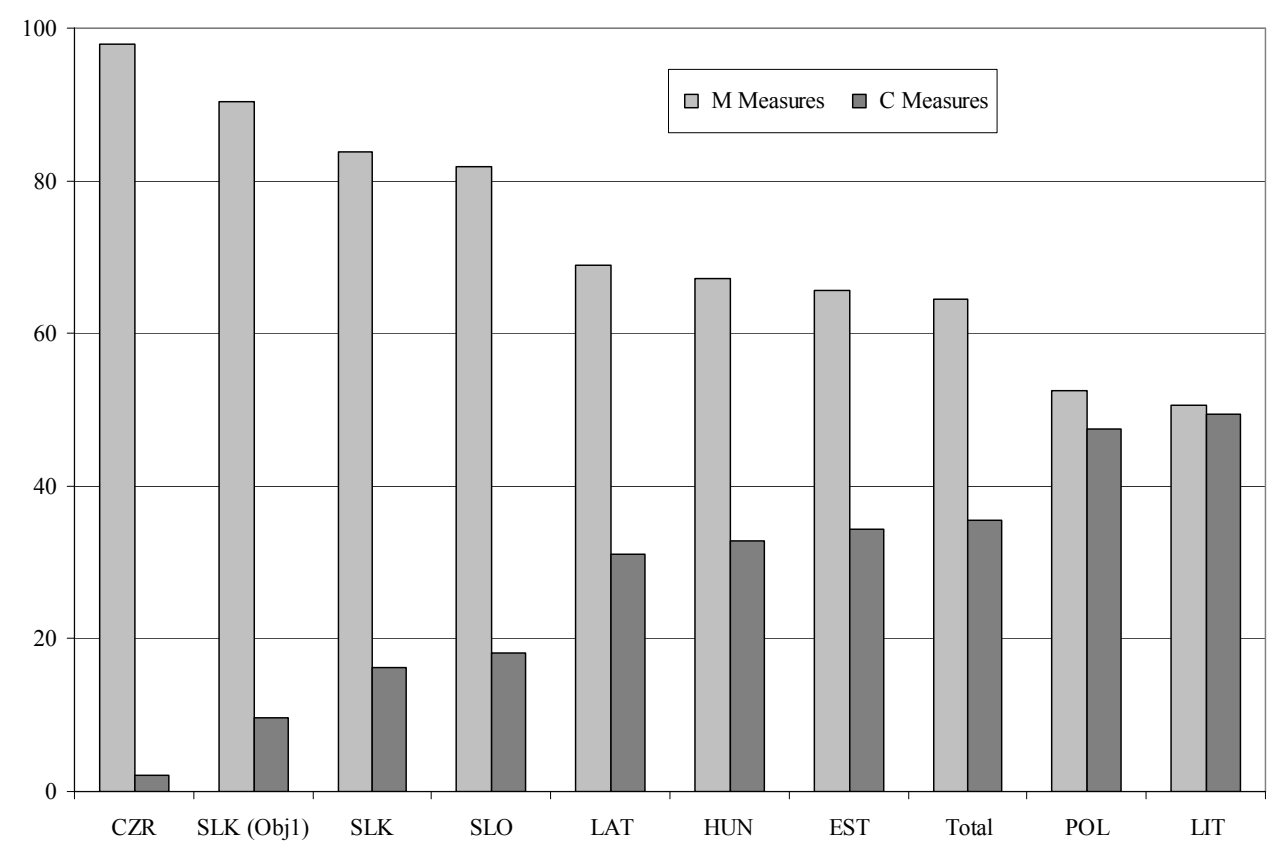

5.2. Single Programming Documents and Operational Programmes: 'Guidance' Funding

The EAGGF Guidance Section contributes less than half of total rural development funding in the NMS, but it is channelled into the majority of measures. It also displays a clear C-orientation. The two most well-funded measures under SAPARD 'investment in farms' and 'processing and marketing of agricultural products' - 
remain so after accession in all countries bar the Czech Republic. The biggest change in the funding of $\mathrm{C}$ measures between SAPARD and the OPs/SPDs is for 'rural infrastructure'. This has been driven by Polish policy choices: pre-accession, this was the second most well-funded measure adopted whereas, post-accession, the public funds Poland directed to this measure were down by over $90 \%$.

Given its magnitude, this change in Poland merits further comment. First, the pre- and post-accession 'rural infrastructure' measures are not fully equivalent in definition and scope. In contrast to SAPARD, the post-accession programmes provide separate infrastructure support through 'investments in farms', 'processing and marketing of agricultural products', 'water management', etc. Moreover, Poland chose to fund post-accession investment in rural infrastructure principally using European Regional Development Fund money, via the Integrated Regional Development OP. As a result, resources have been 'released' under the post-accession framework and directed towards an enriched and re-prioritised rural development package. Further, the OP Complement (page 16) suggested a certain hesitancy about pursuing this measure further: "It was indicated that the measure implementation may result in the occurrence or intensification of social antagonisms as well as intensified economic polarisation among inhabitants of rural areas."

Across the Guidance Section-funded programmes, countries have chosen very different combinations of measures. Only three measures are taken up by all eight countries 9 . Two measures are taken up by only two countries ${ }^{10}$, three are taken up by just one country, ${ }^{11}$ whilst three more ${ }^{12}$ are pursued by no country. 'Basic services for the rural economy' is taken up in three countries, but only in smaller, SPD-submitting NMS. 'Support for tourist and craft activities' is taken up in the three Baltic states, but is otherwise adopted only by Hungary. The NMS are thus making use of the considerable scope for deploying different combinations of measures. That said, Figure 3 shows that all eight countries emphasise $\mathrm{C}$ measures over $\mathrm{M}$ measures, with the four larger OP-submitting countries doing so to a greater extent than the four smaller NMS. 
Figure 3: Take-up of Competitiveness-Oriented and Multifunctionality-Oriented Policy Measures under OPs and SPDs (shares of public funding)

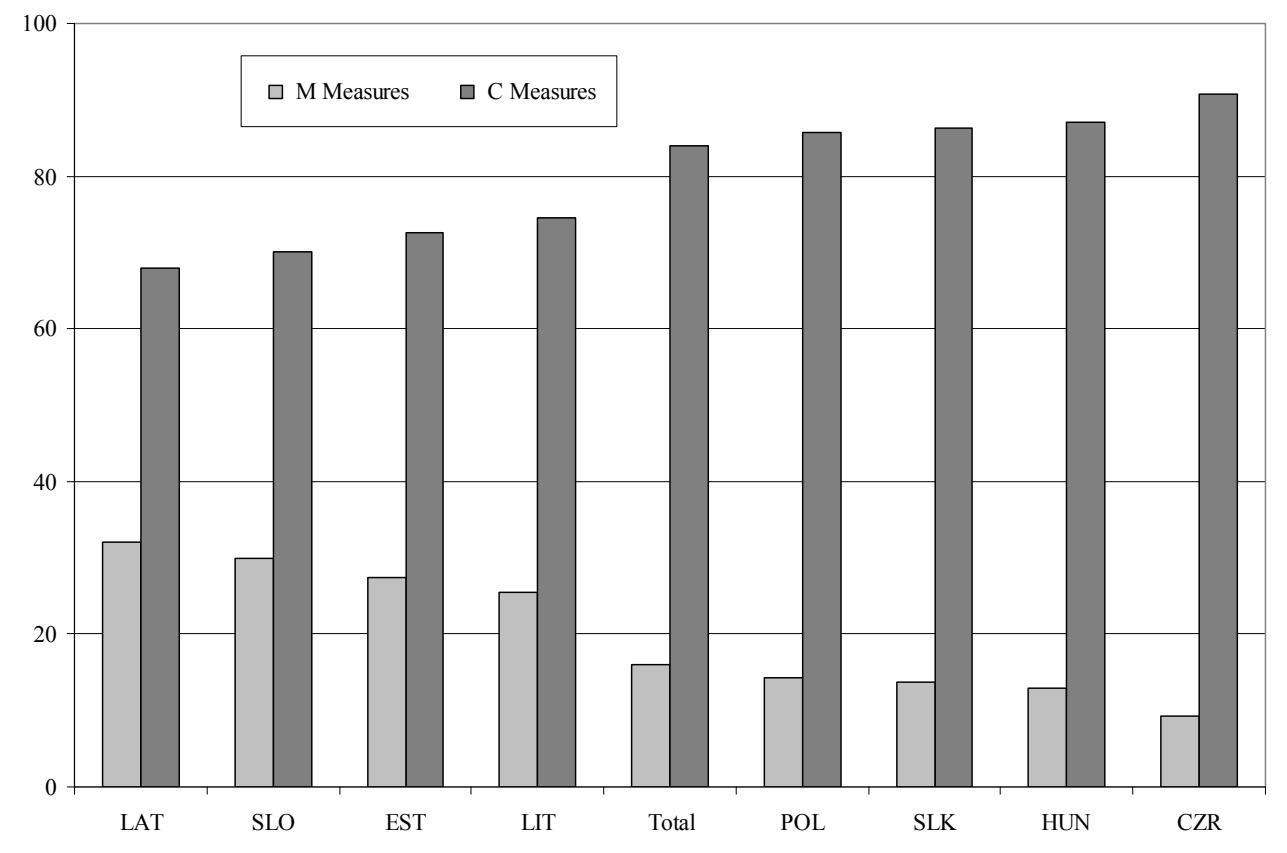

\subsection{Overview of post-accession policy implementation}

The orientation of the different programming documents towards either $\mathrm{M}$ or $\mathrm{C}$ measures reflects the emphasis of the underlying legislation. Article 43(2) of Regulation 1257/1999, the basis for RDPs states, in the first indent, that member states shall in their RDPs "provide for agri-environment measures throughout their territories and in accordance with their specific needs". The second indent adds that the member states must "ensure the necessary balance is kept between the different support measures".

In contrast, OPs and SPDs derive from EU regional policy. Paragraph 1 of the preamble to Regulation 1260/1999 links the policies therein to "Article 158 of the Treaty [which] states that, in order to strengthen its economic and social cohesion, the Community shall aim at reducing disparities between the levels of development of the various regions and the backwardness of the least-favoured regions or islands, including rural areas". Across all post-accession programmes, however, the allocation of public funding between $\mathrm{M}$ and $\mathrm{C}$ measures is more balanced, as shown in Figure 4. 
Figure 4: Take-up of Competitiveness-Oriented and Multifunctionality-Oriented Policy Measures under ALL Post-Accession Policies (shares of public funding)

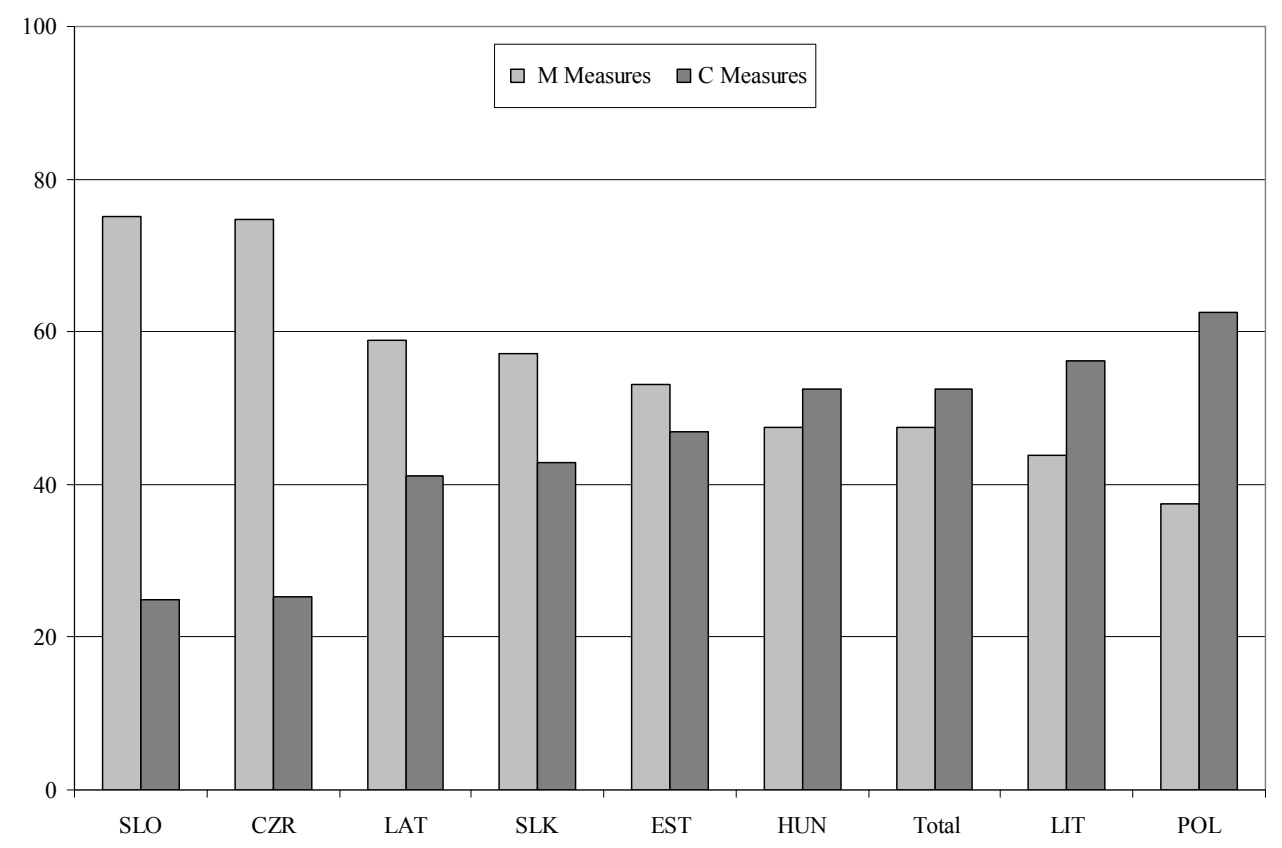

Utilising the quintile-based classification outlined in Section 3, the broad policy orientation by country and by programme can now be identified. Table 3 summarises the preferences revealed by choice of rural development policy measures stating, for each document-type, the share of public funds assigned to $M$ measures. The countries are ranked in the same order as that shown in Figure 4 and confirm more formally the findings described previously. 
Table 3: The Evolution of the New Member States’ Policy Preferences (Public Funds)

\begin{tabular}{|c|c|c|c|c|c|c|c|c|}
\hline & SAPARD & M-funding & RDP & M-funding & OP or SPD & M-funding & $\begin{array}{l}\text { All post-accession } \\
\text { RD funds }\end{array}$ & M-funding \\
\hline Slovenia & $\begin{array}{l}\text { Strong C- } \\
\text { preference }\end{array}$ & $14 \%$ & $\begin{array}{l}\text { Strong M- } \\
\text { preference }\end{array}$ & $82 \%$ & $\begin{array}{l}\text { Moderate C- } \\
\text { preference }\end{array}$ & $30 \%$ & $\begin{array}{l}\text { Moderate M- } \\
\text { preference }\end{array}$ & $75 \%$ \\
\hline Czech Republic & $\begin{array}{l}\text { Moderate C- } \\
\text { preference }\end{array}$ & $30 \%$ & $\begin{array}{l}\text { Strong M- } \\
\text { preference }\end{array}$ & $98 \%$ & $\begin{array}{l}\text { Strong C- } \\
\text { preference }\end{array}$ & $9 \%$ & $\begin{array}{l}\text { Moderate M- } \\
\text { preference }\end{array}$ & $75 \%$ \\
\hline Slovakia & $\begin{array}{l}\text { Moderate C- } \\
\text { preference }\end{array}$ & $26 \%$ & $\begin{array}{l}\text { Strong M- } \\
\text { preference }\end{array}$ & $84 \%$ & $\begin{array}{l}\text { Strong C- } \\
\text { preference }\end{array}$ & $14 \%$ & $\begin{array}{l}\text { Balanced } \\
\text { approach }\end{array}$ & $57 \%$ \\
\hline Estonia & $\begin{array}{l}\text { Moderate C- } \\
\text { preference }\end{array}$ & $25 \%$ & $\begin{array}{l}\text { Moderate M- } \\
\text { preference }\end{array}$ & $66 \%$ & $\begin{array}{l}\text { Moderate C- } \\
\text { preference }\end{array}$ & $28 \%$ & $\begin{array}{l}\text { Balanced } \\
\text { approach }\end{array}$ & $53 \%$ \\
\hline Hungary & $\begin{array}{l}\text { Moderate C- } \\
\text { preference }\end{array}$ & $29 \%$ & $\begin{array}{l}\text { Moderate M- } \\
\text { preference }\end{array}$ & $67 \%$ & $\begin{array}{l}\text { Strong C- } \\
\text { preference }\end{array}$ & $13 \%$ & $\begin{array}{l}\text { Balanced } \\
\text { approach }\end{array}$ & $48 \%$ \\
\hline TOTAL & $\begin{array}{l}\text { Strong C- } \\
\text { preference }\end{array}$ & $19 \%$ & $\begin{array}{l}\text { Moderate M- } \\
\text { preference }\end{array}$ & $65 \%$ & $\begin{array}{l}\text { Strong C- } \\
\text { preference }\end{array}$ & $16 \%$ & $\begin{array}{l}\text { Balanced } \\
\text { approach }\end{array}$ & $48 \%$ \\
\hline Lithuania & $\begin{array}{l}\text { Strong C- } \\
\text { preference }\end{array}$ & $13 \%$ & $\begin{array}{l}\text { Balanced } \\
\text { approach }\end{array}$ & $51 \%$ & $\begin{array}{l}\text { Moderate C- } \\
\text { preference }\end{array}$ & $25 \%$ & $\begin{array}{l}\text { Balanced } \\
\text { approach }\end{array}$ & $44 \%$ \\
\hline Poland & $\begin{array}{l}\text { Strong C- } \\
\text { preference }\end{array}$ & $14 \%$ & $\begin{array}{l}\text { Balanced } \\
\text { approach }\end{array}$ & $53 \%$ & $\begin{array}{l}\text { Strong C- } \\
\text { preference }\end{array}$ & $14 \%$ & $\begin{array}{l}\text { Moderate C- } \\
\text { preference }\end{array}$ & $37 \%$ \\
\hline
\end{tabular}




\section{Analysis of results and policy implications}

The foregoing discussion confirms broad alignment between the $\mathrm{C}$ or $\mathrm{M}$ focus of different legislation and policy uptake in the NMS. Furthermore, as Figure 4 and Table 3 show, the strong policy orientation of individual programmes has not inhibited the NMS from revealing their differing rural development preferences by adopting different combinations of measures. The statistical analysis utilised next to explore these differences further was outlined in Section 3, along with its limitations. The key caveat is worth reiterating.

Whilst this analysis draws upon formal tools, grounded in theory, it does not constitute rigorous hypothesis testing. Rather, correlations are offered as indicating possible influences over policy choice, alongside other policy or political factors including the legislative factors highlighted above. The results presented here are thus offered as a first, partial, analysis of rural development policy choice in the NMS, to be used as a guide to more detailed research, investigating policy choice at a more detailed, disaggregated level (as, for example, Bertoni et al do, as noted earlier).

Table 4: Correlation Coefficients (r) for Policy Uptake, public funding

\begin{tabular}{|c|c|c|c|c|}
\hline & $\begin{array}{l}\text { M share } \\
\text { SAPARD }\end{array}$ & $\begin{array}{c}\text { M share } \\
\text { RDP }\end{array}$ & $\begin{array}{l}\text { M share } \\
\text { OP/SPD }\end{array}$ & $\begin{array}{c}\text { M share } \\
\text { Overall post- } \\
\text { accession funding }\end{array}$ \\
\hline GDP per capita & 0.0008 & $0.6873^{*}$ & -0.2032 & $0.7420 * *$ \\
\hline Agricultural output (\% in GDP) & -0.2759 & $-0.8873 * * *$ & 0.2824 & $-0.7712 * *$ \\
\hline $\begin{array}{l}\text { Utilised agricultural area (UAA) } \\
(\% \text { in total area) }\end{array}$ & 0.0622 & -0.0208 & $-0.8569 * * *$ & -0.3556 \\
\hline Forested area ( $\%$ in total area) & 0.2000 & 0.3161 & $0.6946^{*}$ & 0.5766 \\
\hline Average farm size & n.a. & $0.7482 * *$ & -0.5255 & 0.5445 \\
\hline Agricultural employment & 0.0924 & $-0.7729 * *$ & 0.3401 & -0.5865 \\
\hline Organic farming ( $\%$ in UAA) & 0.0782 & $0.8232 * *$ & -0.2779 & $0.7571 * *$ \\
\hline
\end{tabular}

Sources: National programme documents; Eurostat; own calculations.

Notes. * significant at $10 \% ; * *$ significant at $5 \% ; * * *$ significant at $1 \%$.

Spending data include 'Technical Assistance'

Table 4 summarises the coefficients on correlations between several economic variables and the share of public rural development funding assigned to $\mathrm{M}$ measures. 1999 data are used for the pre-accession analysis and 2003 data for the post-accession 
analysis, dates chosen to reflect conditions when the policy choices were being made. The discussion below focuses on the post-accession policy choices, for which there was both greater choice and greater freedom of choice. A few comments on preaccession policy uptake follow later.

GDP per capita reflects a country's general level of economic development. A link may be expected with a country's rural development preferences, if lower levels of economic development are associated with larger and less efficient agricultural sectors which may, in turn, result in a greater demand/need for C-oriented funding. At higher income levels, with a smaller and more efficient agricultural sector, demand may rise for M-type support (this has similarities with the hypothesis that demand for environmental goods is income elastic, although the two analyses are not congruent). The results in Table 4 confirm these expectations. The sign on the share of spending going to $\mathrm{M}$ measures in the (C-oriented) OPs and SPDs is negative but insignificant.

The share of agricultural output in GDP can be seen as a parallel, sectoral, indicator of a country's development: the more developed a country, the smaller the share of the agricultural sector in GDP, broadly speaking. It may thus be assumed that a higher percentage share for agriculture indicates a less developed sector, suggesting a relatively high demand for $\mathrm{C}$ measures at the expense of multifunctionality. This conjecture is also supported, with the statistic particularly strong on $\mathrm{M}$ measures implemented through RDPs. Again the coefficient on the (minority) M measures implemented through C-oriented OPs and SPDs is incorrectly signed but insignificant.

The next two indicators examine the possible effect of aspects of land-use in the NMS on the $\mathrm{C} / \mathrm{M}$ balance of their rural development choices. A large share of utilised agricultural area (UAA) in a country's total land area may indicate a larger agricultural sector and thus, for similar arguments to those presented above for agriculture's share of GDP, indicate greater demand for C measures. On the other hand, a significant share of forested area in total land area may be associated with a greater awareness of and demand for $\mathrm{M}$ measures. Furthermore, support for more afforestation is available via some M-oriented rural development measures. Importantly, the coefficients on the cross-correlations between GDP share, UAA and forested area, not reported here, are tiny and insignificant. 
The assumed interactions between land use and the balance of demand for $\mathrm{C}$ and $\mathrm{M}$ measures may, however, not be so simple. For example, a country with a high share of UAA and a large (and possibly inefficient) farm sector may seek to improve competitiveness with a rural development policy-mix combining targeted C-measures (e.g. investment in farms, early retirement, semi-subsistence farm support) and selected M-measures (such as diversification of agricultural activities), with nonfarming rural activities promoted to help maintain the rural population and promote balanced national economic development. These caveats notwithstanding, the signs on the coefficients are consistent with ex ante expectations - although only those on measures adopted via OPs and SPDs are high enough to register significance at $10 \%$ or better.

The next two indicators, average farm size and agricultural employment, develop further the idea that the $\mathrm{C} / \mathrm{M}$ mix might be influenced by the structure of the farm sector (although the longer-term impact of post-transition changes is still unfolding). To the extent that smaller holdings are associated with lower efficiency, it can be expected that countries with smaller average farm sizes have a greater need for $\mathrm{C}$ measures over $\mathrm{M}$ measures. The cross-correlation between average farm size and agricultural output as a share of national GDP is negative and significant at the 5\% level, confirming the earlier expectation of a link between farm structures and levels of economic development. An analysis of diseconomies of scale is beyond the scope of this paper, but whilst some measures provide de facto support to make farms larger, no support is offered to make farms smaller, suggesting that policy-makers do not see diseconomies of scale as a binding constraint.

As for agricultural employment levels, they may be presumed to be negatively linked to spending on $\mathrm{M}$ measures, since a higher share of the total population engaged in agriculture is likely to be aligned with low sectoral efficiency and thus a greater need for targeted (and principally C-oriented) adjustment. Yet, as shown above, certain Mtype measures can also be directed to the same objective, which may impact on the correlations (this indicates why further disaggregated case-study analysis of policy take-up is merited). That said, the results show the signs on the coefficients are as expected for the RDPs and for total post-accession funding, although only those 
associated with RDP measures are significant (at 5\%). As with the first two variables, the coefficients on the OP/SPD data are incorrectly signed but insignificant.

The last of the seven variables concerns organic farming. Although this is gaining importance in the NMS (European Environmental Bureau, 2003), its spread is unevenly distributed. This is reflected in the post-accession policy choices of the NMS, where countries with higher shares of organic agriculture also allocate relatively more funding to $\mathrm{M}$ measures via their rural development policies (the extent of the market for organic products may be assumed to reflect the attitude of a country, its citizens and its farmers towards M-oriented measures more generally). It is again RDPs - through which funding for organic agriculture is channelled - and overall funding that have the expected signs on the coefficients, with both significant at 5\% (in the case of RDP funding, close to 1\%). Again, funding channelled through the OPs and the SPDs displays an incorrect sign but on a statistically insignificant coefficient.

Note that of 21 cross-correlations between the variables in Table 4, only five are significant at $10 \%$ or more. One has already been discussed; the other four are between the share of organic farming in national UAA and, variously, GDP per capita (positive sign, significant at 10\%), agricultural output as a percentage of GDP (negative, 10\%), average farm size (positive, 1\%) and agriculture's share of employment (negative, 5\%). These results all indicate strong connections between a country's (economic and sectoral) development, sectoral efficiency and the state of development of the organic sector. The other results, not reported here, are available from the authors on request.

The results in Table 4 show that the signs on most coefficients in the post-accession analysis conform to a priori expectations, albeit with varying correlation 'strength'. Selected economic factors influencing the M-orientation of policy adoption are thus identified at the aggregate level, notwithstanding the large number of other factors influencing the take-up of individual measures. With countries' pre-accession (SAPARD) policy choices, however, the results show that the selected variables had little or no influence. Moreover, Table 3 showed how similar the cross-country funding split between $\mathrm{C}$ and $\mathrm{M}$ measures was under SAPARD: four countries exhibited a strong C-orientation, four a moderate C-orientation. This highlights the 
pervasive influence of the legislative constraints on countries' SAPARD choices, as discussed in Section 4, with the measures adopted unable to reflect the highly differentiated domestic agricultural circumstances present across the eight countries.

Nevertheless, SAPARD was not the only pre-accession channel of rural development support, as it complemented national resources and other foreign (EU included) programmes. Moreover, even if the implementation of SAPARD meant less countrydifferentiation than objectively needed, the merits of SAPARD should be seen more widely. The programme - and especially its approach to M measures - was explicitly part of a learning process that triggered or speeded up necessary adjustment in the rural sectors of these countries and consisted not only of a transfer of funds but also of administrative capacity and know-how.

Next, a few comments on the one rural development measure excluded from the foregoing analysis - reverse-modulation or 'complements to direct payments' (CDP). This was excluded, as noted previously, because the money is used to support Pillar I measures. As it represents money removed from Pillar II, however, some comments are appropriate, in the light of how the remaining Pillar II funds were spent.

Total planned CDP spending of $€ 1026$ million represents about $15 \%$ of public rural development funds (excluding technical assistance) available to the NMS. A priori, these sums could be positively or negatively correlated with shares of rural development funds devoted to $\mathrm{M}$ measures. Assuming $\mathrm{CDP}$ are aligned with $\mathrm{C}$ oriented rural development measures and Pillar I policy objectives, a positive correlation might suggest CDP were being utilised to set against rural development M-spending, as part of a CAP-wide balanced approach to policy implementation across both CAP Pillars. A relatively large sum devoted to CDP would be matched by a relatively large share of remaining rural development funds assigned to $\mathrm{M}$ measures. A negative correlation, on the other hand, might suggest CDP were being utilised to boost Pillar I policy goals, alongside a C-oriented use of Pillar II funds. The NMS' approach to CDP would thus mirror their approach to $\mathrm{C}$ measures in implementing rural development, at the double expense of $\mathrm{M}$ measures. 
The result confirms the latter hypothesis. The coefficient between CDP as a share of RDP spending and the share of M-oriented measures in public RDP funding, significant at $5 \%$, is -0.7614 . The equivalent coefficient on public spending through all post-accession documents and programmes is -0.6095 , just below the critical value for $10 \%$ significance.

More generally, reverse-modulation takes resources from Pillar II measures and redirects them into Pillar I payments. Moreover, in the NMS there will be no compulsory modulation of Pillar I funds into rural development before 2013. Both of these limit the extent to which multifunctionality can actively be promoted in the NMS. That said, on balance the NMS are allocating substantial shares of available public funds to $\mathrm{M}$ measures, whilst utilising widely-ranging combination of measures, in order to implement a multifunctional agriculture in accordance with both EU policy goals and differing domestic policy needs.

Finally, although a detailed analysis of rural development policy take-up in the EU15 is beyond the scope of this paper, a few comments comparing the EU15 and NMS are appropriate. Storti et al (2004: 12) identify, for each EU15 country, the share of total public funding assigned to each measure. Applying our analytical framework to their dataset, six countries adopt a balanced approach (from Belgium, with $48 \%$ of funds assigned to $\mathrm{M}$ measures, through France, Luxembourg, the Netherlands and Spain to Greece, with a $57 \%$ allocation), three countries exhibit a moderate $\mathrm{M}$ preference (Denmark, Italy and Germany), with the rest revealing a strong $\mathrm{M}$ preference (from Ireland at $82 \%$ to Finland at $98 \%$; the UK figure is $94 \%$ ). In addition to spending assigned to specific measures, each country has a sum for 'other' spending, ranging from $3.1 \%$ of the total in Portugal to $36.9 \%$ in Belgium. This principally reflects payments for measures from the previous planning period carried over to the current period. Not knowing how this money is split between $\mathrm{M}$ and $\mathrm{C}$ measures, it has been divided in equal proportion to the known split of current-period funds between $\mathrm{M}$ and $\mathrm{C}$ measures and added to the totals.

Even though this might introduce a small error, the general picture is that the majority of these richer countries are promoting $\mathrm{M}$ measures. Belgium, ranked lowest, has the same M-share (48\%) as the NMS8 average - although the latter figure is influenced 
by Poland with its 37\% M-share. Given the pursuit by France of an "agrarian agenda" (Lowe et al, 2002, discussed earlier), it is interesting to note that they have the second lowest $\mathrm{M}$-share, at just over $52 \%$. At the other end, the highest $\mathrm{M}$-share amongst the NMS (75\% in the Czech Republic and Slovenia) is lower than the six EU15 countries exhibiting a strong M-preference and is only just above the EU15 average of $73.25 \%$. Within the NMS, richer countries have been shown to tend to promote M measures more. A comparison of the NMS and EU15 suggests the same general principle applies between the two groups of countries. Note, however, that because rural development funds represent about $10 \%$ of CAP spending in the EU15 but about $40 \%$ in the NMS, the relative importance of M measures across the CAP as a whole is greater in the NMS than the EU15.

\section{Conclusions}

Recent CAP reforms have extended the scope of policy goals and instruments and introduced to the policy a new two-Pillar structure. Pillar II, rural development, has been the channel through which measures aligned with multifunctionality have been introduced. Broadly speaking, these measures promote either environmentallyfriendly farming or diversification and the economic health of rural communities, although Pillar II also includes several competitiveness-oriented measures.

Member states implement rural development policy by choosing from a long list of individual measures. This paper has focused on the start of the rural development programming process for the (central and eastern European) NMS, examining which measures they adopted, before and after accession. It has developed a taxonomy for policy choice that indicates the extent to which multifunctionality is being promoted. The classification of rural development measures as either competitiveness-oriented (C) or multifunctionality-oriented $(\mathrm{M})$ is rooted in the literature on multifunctionality and in the approach taken by the European Commission. The numeraire used in comparing the two sets of measures is the public funding assigned to each. The scope of the current analysis, covering the full set of pre- and post-accession rural programming documents, underscores the novel approach taken.

Under the pre-accession SAPARD programme, the applicants chose predominantly Coriented measures. There were, however, a number of legislative constraints on policy 
adoption that dictated this outcome. Post-accession, these constraints were removed and the number of available measures increased, as a result of which most countries allocated equal or greater shares to $\mathrm{M}$ measures. Within this result, measures adopted via Rural Development Plans and funded from the EAGGF Guarantee Section revealed an M-orientation; whereas measures adopted via Operational Programmes or Single Programming Documents, funded from the EAGGF Guidance Section, had a C-orientation.

Using a taxonomy of policy preferences developed for this paper, all countries exhibited moderate or strong C-preferences in their SAPARD policy choices. Postaccession, however, five of the eight countries pursued a balanced adoption of $\mathrm{M}$ and $\mathrm{C}$ measures, two countries showed a moderate M-preference, whilst Poland showed a moderate C-preference. This contrasts with choices made by the richer EU15 countries, where six pursued a balanced approach, three exhibited a moderate $M$ preference and six a strong M-preference. It is therefore possible that, in the long term, the NMS may increase their M-share of public funding as growth and rising wealth lift the demand for M-measures.

In order to seek to understand further the policy choices of the NMS, correlations were calculated between $\mathrm{M}$ spending shares and selected economic variables, overall and for individual programmes. The estimated correlations indicated that all the economic variables chosen are likely to have had at least some influence on policy take-up. Countries appear more likely to allocate public funds to $\mathrm{M}$ measures if they were richer, with smaller, more efficient agricultural sectors. That said, the analysis presented here should not be interpreted as constituting formal hypothesis testing. It is instead offered as a formal but descriptive initial investigation into some possible factors that may be influencing countries' take-up of rural development policies. From this starting point, further quantitative or qualitative case-study analyses will be able to shed further light on, for example, policy choices in particular countries, or the popularity (or not) of individual measures.

\section{Acknowledgements}

The authors wish to thank Mike Pearson and two anonymous referees for their extremely helpful comments on this paper. The usual disclaimer applies. 


\section{References}

For each country there were four official documents drawn upon: the three programming documents for SAPARD, RDPs and either OPs or SPDs. In addition, there was the "Programme Complement" to the OPs/SPDs. Full bibliographic details of all 32 documents can be obtained from the authors.

Barthelemy, D. and Nieddu, M. (2004) Multifunctionality as a concept of duality in economics; an institutionalist approach. Paper presented to the $90^{\text {th }}$ EAAE seminar "multifunctional agriculture, policies and markets: understanding the critical linkages", Rennes, 28-29 October.

Bertoni, D., Peri, M. and Olper, A. (2005) Implementation of EU agri-environmental measures at the regional level: economic and political constraints. Paper presented to the $99^{\text {th }}$ EAAE seminar "the future of rural Europe in the global agri-food system”, Copenhagen, 24-27 August.

Boisvert, R.N. and Blandford, D (2005) Multifunctionality and non-trade concerns: implications for future agricultural policy in Asia. Paper presented at the Conference on "Management of Paddy and Water Environment for Sustainable Rice Production", Kyoto, Japan, September 7-8, 2005.

Durand, G. and van Huylenbroeck, G. (2003) Multifunctionality and rural development: a general framework. In Multifunctional Agriculture: a new paradigm for European agriculture and rural development, pp. 1-16, van Huylenbroeck, G. and Durand, G. (eds). Ashgate, Aldershot.

European Commission (1997) The Agricultural Situation in the European Union: 1996 Report. Office for Official Publications of the European Communities, Luxembourg.

European Commission (2003) Fact Sheet: Overview of the implementation of Rural Development Policy 2000-2006. Office for Official Publications of the European Communities, Luxembourg.

European Commission (2005) Report from the Commission to the European Parliament, the Council, the European Economic and Social Committee and the Committee of the Regions: SAPARD Annual Report - year 2004. COM(2005)537 final. Brussels, 28.10.2005. 
European Environment Agency (2004) Agriculture and the environment in the EU accession countries: Implications of applying the EU common agricultural policy. Environmental issue report No 37. European Environment Agency, Copenhagen.

European Environmental Bureau, 2003. Is organic farming an alternative for the New Member States? Report 2003/016. European Environmental Bureau, Brussels.

Garzon, I. (2005) Multifunctionality of agriculture in the European Union: Is there substance behind the discourse's smoke? Center on Institutions and Governance Presentation Paper No. 20. Institute of Governmental Studies, University of California, Berkeley CA.

Konečný, M. (2004) EU Enlargement and Agriculture: risks and opportunities. Friends of the Earth Europe, Brussels.

Lehtonen, H., Lankoski, J. and Niemi, J. (2005) Evaluating the impact of alternative agricultural policy scenarios on multifunctionality: a case study of Finland. ENARPRI Working Paper No. 13. CEPS, Brussels.

Lowe, P., Buller, H. and Ward, N. (2002) Setting the next agenda? British and French approaches to the second Pillar of the Common Agricultural Policy. Journal of Rural Studies 18, 1-17.

Network of Independent Agricultural Experts in the CEE Candidate Countries (2004) The Future of Rural Areas in the CEE New Member States. Institut für Agrarentwicklung in Mittel-und Osteuropa, Halle.

OECD (2001) Multifunctionality: Towards an analytical framework. Organisation for Economic Cooperation and Development, Paris.

Potter, C. and Burney, J. (2002) Agricultural multifunctionality in the WTO legitimate non-trade concern or disguised protectionism? Journal of Rural Studies $18,35-47$.

Potter, C. and Tilzey, M. (2005) Agricultural policy discourses in the European postFordist transition: neoliberalism, neomercantilism and multifunctionality. Progress in Human Geography 29, 581-600.

Râmniceanu, I. (2004) Questioning Rural Development in an Enlarging EU: The Case of Romania. Working Paper No. 9, European Institute of Romania, Bucharest.

Rodríguez Rodríguez, M., Galdeano Gómez, E. and Céspedes Lorente, J. (2004) Rural multifunctionality in Europe: the concept and policies. Paper presented to the $90^{\text {th }}$ EAAE seminar "multifunctional agriculture, policies and markets: understanding the critical linkages", Rennes, 28-29 October. 
Storti, D., Henke, R. and Macri, M.C. (2004) The new European rural policy: a comparative analysis across regions in the EU. Paper presented to the $87^{\text {th }}$ EAAE seminar "assessing rural development policies of the CAP", Vienna, 21-24 April.

Swinbank, A. and Daugbjerg, C. (2006) The 2003 CAP Reform: Accommodating WTO Pressures. Comparative European Politics 4, 47-64.

Ward, N. and Lowe, P. (2004) Europeanizing rural development? Implementing the CAP's second Pillar in England. International Planning Studies 9, 121-137.

${ }^{1}$ Council Regulation 1698/2005 of 20 September 2005, on support for rural development by the European Agricultural Fund for Rural Development (EAFRD). Official Journal of the European Communities, L277, pp. 1-40.

2 The 'core' Regulation is Council Regulation (EC) No 1257/1999 of 17 May 1999 (OJ L 160, 26.6.1999, p. 80), amended by Council Regulations: 1783/2003 (OJ L 270, 21.10.2003), 567/2004 (OJ L 90, 27.3.2004) and 583/2004 (OJ L 91, 30.3.2004). Detailed rules applying 1257/1999 are provided by Commission Regulation 817/2004 (OJ L 153, 30.4.2004). Rules applying rural development in the NMS are given in Commission Regulation 141/2004 (OJ L 24, 29.1.2004) - see also detailed by Commission Regulation 27/2004 (OJ L 005, 9.1.2004), amended by Commission Regulation 740/2004 (OJ L 116, 22.4.2004).

${ }^{3}$ The basis for OPs/SPDs is Regulation (EC) No 1260/1999 of 21 June 1999 laying down general provisions on the Structural Funds (OJ L 161, 26.6.1999).

${ }^{4}$ The focus of this paper is the policy choices made by the applicants from the policy menu faced. For details on the implementation of SAPARD see, inter alia, European Commission, 2005.

${ }^{5}$ Council Regulation (EC) No 1268/1999 of 21 June 1999, Official Journal of the European Communities, L161, pp. 87-93.

${ }^{6}$ Setting up farm relief and farm management services; establishment and updating of land registers; agricultural water resources management.

${ }^{7}$ Investment in farms; processing and marketing; diversification; technical assistance.

${ }^{8}$ Developing rural infrastructure; promoting environmentally-friendly agriculture; vocational training.

${ }^{9}$ investment in farms; processing/marketing; diversification.

${ }^{10}$ setting up farm advisory services; marketing of quality agricultural products.

${ }^{11}$ restoring agricultural production; use of farm advisory services; environmental protection.

12 farmers' participation in food quality schemes; producer group activities related to food quality; protecting the environment and financial engineering. 